\title{
Sulfentrazone plus a Low Rate of Halosulfuron for Weed Control in White Bean (Phaseolus vulgaris L.)
}

\author{
Allison N. Taziar1, Nader Soltani' ${ }^{1}$, Christy Shropshire1, Darren E. Robinson', Mitch Long', \\ Chris L. Gillard1', Peter H. Sikkema1 \\ ${ }^{1}$ University of Guelph Ridgetown Campus, Ridgetown, Canada \\ ${ }^{2}$ FMC Corporation, Saskatoon, Canada \\ Email: soltanin@uoguelph.ca
}

How to cite this paper: Taziar, A.N., Soltani, N., Shropshire, C., Robinson, D.E., Long, M., Gillard, C.L. and Sikkema, P.H. (2017) Sulfentrazone plus a Low Rate of Halosulfuron for Weed Control in White Bean (Phaseolus vulgaris L.). Agricultural Sciences, 8, 227-238.

https://doi.org/10.4236/as.2017.83016

Received: December 26, 2016

Accepted: March 7, 2017

Published: March 10, 2017

Copyright $\odot 2017$ by authors and Scientific Research Publishing Inc. This work is licensed under the Creative Commons Attribution International License (CC BY 4.0).

http://creativecommons.org/licenses/by/4.0/

(c) †) Open Access

\begin{abstract}
Halosulfuron was recently registered as the second soil-applied herbicide for broadleaf weed control in Ontario dry beans, but does not provide an alternative mode of action. Sulfentrazone is used to control broadleaf weeds in soybean and other pulse crops, and its registration for Ontario dry beans would provide a different mode of action for broadleaf weed control. Five field studies were conducted over two years $(2014,2015)$ to determine if the spectrum of broadleaf weed control is improved by adding a half-rate of halosulfuron to sulfentrazone PRE, and to determine the tolerance of white bean to sulfentrazone (140 or $210 \mathrm{~g}$ ai ha ${ }^{-1}$ ), s-metolachlor (1050 $\mathrm{g}$ ai ha $\mathrm{ha}^{-1}$ ), and halosulfuron $\left(17.5 \mathrm{~g}\right.$ ai ha $\left.{ }^{-1}\right)$ applied alone and in combination. Crop injury was assessed at 2 and 4 weeks after crop emergence. Weed control was assessed at 4 and 8 weeks after herbicide application (WAA), and weed density and biomass were determined at 8 WAA. Seed moisture and yield were determined at harvest. Halosulfuron added to sulfentrazone improved the control of Ambrosia artemisiifolia and Sinapis arvensis. Sulfentrazone $+\mathrm{s}$-metolachlor + halosulfuron caused up to $23 \%$ crop injury. Therefore, this study concludes that sulfentrazone $+s$-metolachlor + halosulfuron provides broad spectrum weed control, but is too injurious to white bean for registration in Ontario.
\end{abstract}

\section{Keywords}

Biomass, Density, Injury, Height, Navy Bean, Phaseolus vulgaris L.

\section{Introduction}

Dry edible beans (Phaseolus vulgaris L.) are a staple food that fit well in a typical 
Ontario crop rotation of corn, soybean and wheat. Several market classes of dry beans are grown in Ontario including cranberry, black, Dutch brown, kidney, small red Mexican, otebo, pinto, yellow eye and white (navy) bean. White bean is the predominant class of dry bean grown in Ontario, accounting for approximately $50 \%$ of production [1] [2].

One of the most critical aspects of crop management for dry bean producers is weed control, as dry beans are poor competitors [3]. In Ontario, weed interference has caused white bean yield losses of $68 \%$ to $77 \%$ [4] [5] [6]. Weeds can also affect bean quality at harvest by staining the seed coat, producing unwanted aromas, or contaminating the beans with foreign plant parts. When used in efficacious tank mix combinations that do not injure the crop, herbicides are effective tools for controlling weeds.

Sulfentrazone is a protoporphyrinogen oxidase IX (PPO) inhibitor herbicide in the aryl triazinone family and was recently registered Canada-wide for preemergence (PRE) application in chickpea (Cicer arientinum L.), soybean (Glycine $\max$ L.), sunflower (Helianthus annuus L.), flax (Linum usitatissimum L.) and field pea (Pisum sativum L.). Sulfentrazone is taken up by germinating weeds and is translocated to the shoot, where it inhibits the PPO enzyme and causes an excess of protoporphyrinogen IX. Various reactions occur in the cytoplasm resulting in the conversion of protoporphyrinogen IX to $\mathrm{O}^{+}$radicals, which disrupt the cell membranes and cause loss of cell function [7] [8]. Sulfentrazone primarily controls broadleaf species such as common lambsquarters (Chenopodium album L.), common waterhemp (Amaranthus tuberculatus var. rudis), and redroot pigweed (Amaranthus retroflexus L.), as well as annual grasses including Digitaria (crabgrass), Panicum and Setaria (foxtail) species [9] [10] [11].

In 2014, halosulfuron was available for the first time for use in Ontario. Halosulfuron is a sulfonyl urea herbicide, used in dry beans, corn (field, seed, sweet and popcorn-Zea mays L.) and various vegetable crops for broadleaf weed control. Halosulfuron controls common Ontario weed species such as common ragweed (Ambrosia artemisiifolia L.), common lambsquarters, wild mustard (Sinapis arvensis L.), redroot pigweed, flower-of-an-hour (Hibiscus trionum L.), and velvetleaf (Abutilon theophrasti L.) [12]. Several studies have shown that dry beans have excellent tolerance to halosulfuron applied PRE [4] [5].

$\mathrm{S}$-metolachlor is a chloroacetamide herbicide and is currently the only grass herbicide registered for PRE application in dry bean. S-metolachlor controls grass species such as Digitaria spp. (crabgrass), Echinochloa crusgalli (L.) Beauv. (barnyard grass), Panicum capilare L. (witchgrass), Panicum dichotomiflorum (L.) Michx. (fall panicum), and Setaria spp. [13].

Currently, halosulfuron and imazethapyr are the only soil-applied herbicides registered for broadleaf weed control in Ontario dry beans, and are both ALS inhibitor herbicides. As there are currently ten ALS inhibitor-resistant weed species in Ontario, dry bean growers will have difficulty controlling these weeds without another mode of action [14]. This study aimed to determine the toler- 
ance of white bean to tank mixes of sulfentrazone + s-metolachlor + halosulfuron and to determine if a low dose of halosulfuron added to sulfentrazone would improve the spectrum of broadleaf weed control.

\section{Materials and Methods}

\subsection{Experimental Design}

Five field studies were conducted over a two-year period $(2014,2015)$ at the University of Guelph Ridgetown Campus (Ridgetown) and Huron Research Station (Exeter) in Ontario, Canada. The 2014 site in Exeter was a clay loam soil of $31 \%$ sand, $42 \%$ silt and $27 \%$ clay, and had a $\mathrm{pH}$ of 7.8 and organic matter content of $4.3 \%$. In 2015, the Exeter sites were both a loamy soil, with the first site consisting of $32 \%$ sand, $42 \%$ silt and $26 \%$ clay, $\mathrm{pH}$ of 7.7 and organic matter content of $3.2 \%$, and the second site consisting of $35 \%$ sand, $43 \%$ silt, $22 \%$ clay, a $\mathrm{pH}$ of 7.6 and organic matter content of $3.6 \%$. In Ridgetown, the soil at both sites was a sandy clay loam. The first site had a sand, silt, and clay content of $52 \%, 24 \%$, and $24 \%$, respectively, a $\mathrm{pH}$ of 7.3 and organic matter content of $4.3 \%$. The second site had a sand, silt, and clay content of $46 \%, 27 \%$, and $27 \%$, respectively, a $\mathrm{pH}$ of 6.4 and an organic matter content of $3.7 \%$. All sites were prepared by moldboard ploughing in the fall followed by two passes with an s-tine cultivator and rolling baskets in the spring. Plots were $3 \mathrm{~m}$ by $10 \mathrm{~m}$ in Exeter and $3 \mathrm{~m}$ by $8 \mathrm{~m}$ in Ridgetown. All plots were seeded with white bean variety “T9905" (obtained from Hensall District C0-operative, 1 Davidson Drive, Hensall, ON, N0M 1X0, Canada) at a rate of approximately 233,000 seeds ha ${ }^{-1}, 4$ to $5 \mathrm{~cm}$ deep in rows spaced $75 \mathrm{~cm}$ apart. Plots were not irrigated and were fertilized according to Ontario Ministry of Agriculture, Food and Rural Affairs field crops guidelines [14].

Experiments were arranged in a randomized complete block design with four replicates of thirteen treatments. An untreated weedy control and a weed-free control (sprayed with s-metolachlor (1050 $\left.\mathrm{g}_{\text {ai ha }}{ }^{-1}\right)+$ halosulfuron $\left(35 \mathrm{~g} \mathrm{ai} \mathrm{ha}^{-1}\right)$ PRE and maintained weed-free by hand-hoeing) were included in each replicate. Herbicide treatments included PRE applications of sulfentrazone (140 and $210 \mathrm{~g}$ ai $\mathrm{ha}^{-1}$ ), half the registered rate of halosulfuron (17.5 $\mathrm{g}^{\mathrm{ai} \mathrm{ha}} \mathrm{ha}^{-1}$ ), and s-metolachlor (1050 $\mathrm{g} \mathrm{ai} \mathrm{ha}^{-1}$ ) for grass control, used alone and in various combinations (Table 1). Herbicides were applied PRE one day after planting with a pressurized $\mathrm{CO}_{2}$ backpack sprayer and $1.5 \mathrm{~m}$ handheld boom with four ULD 120-02 nozzles (Hypro, New Brighton, $\mathrm{MN}$ ) spaced $50 \mathrm{~cm}$ apart, calibrated to deliver $200 \mathrm{~L} \cdot \mathrm{ha}^{-1}$ at $240 \mathrm{kPa}$.

Crop injury was visually assessed at 2 and 4 weeks after crop emergence (WAE) by comparing the herbicide treatments to the weed-free control, and weed control was visually assessed at 4 and 8 weeks after herbicide application (WAA) by comparing the herbicide treatments to the weedy control. Herbicide treatments were given a score between $0 \%$ (no injury or weed control) to $100 \%$ (complete plant death). At 8 WAA, weed density and biomass were determined by counting the number of plants by species in $1 \mathrm{~m}^{2}$ per plot, followed by cutting 
Table 1. Mean visible injury, seed moisture, and yield at harvest (adjusted to $18 \%$ moisture) of white bean treated with various tank mixes of sulfentrazone, s-metolachlor and halosulfuron applied PRE in five field studies at the University of Guelph Ridgetown Campus, Ridgetown, ON and Huron Research Station, Exeter, ON over a two-year period $(2014,2015)^{\mathrm{a}}$.

\begin{tabular}{|c|c|c|c|c|c|c|c|c|c|}
\hline \multirow{3}{*}{$\begin{array}{c}\text { Treatment } \\
\text { Untreated Control }\end{array}$} & \multirow{3}{*}{$\frac{\text { Rate }}{\left(\mathrm{g} \mathrm{ai} \mathrm{ha}^{-1}\right)}$} & \multicolumn{4}{|c|}{ Dry bean injury (\%) } & \multirow{2}{*}{\multicolumn{2}{|c|}{$\begin{array}{c}\text { Seed moisture } \\
(\%)\end{array}$}} & \multirow{2}{*}{\multicolumn{2}{|c|}{$\begin{array}{l}\text { Yield } \\
\left(\mathrm{T} \mathrm{ha}^{-1}\right)\end{array}$}} \\
\hline & & \multicolumn{2}{|c|}{$2 \mathrm{WAE}$} & \multicolumn{2}{|c|}{$4 \mathrm{WAE}$} & & & & \\
\hline & & 0 & a & 0 & a & 17.5 & $\mathrm{ab}$ & 1.2 & g \\
\hline Weed-free Control & & 0 & a & 0 & a & 16.8 & a & 2.7 & a \\
\hline S-metolachlor & 1050 & 2 & $a b c$ & 3 & $a b c$ & 17.2 & $\mathrm{ab}$ & 1.5 & defg \\
\hline Sulfentrazone & 140 & 5 & $a b c$ & 5 & $a b c$ & 17.3 & $\mathrm{ab}$ & 1.3 & fg \\
\hline Sulfentrazone & 210 & 10 & bcde & 10 & bcd & 17.4 & $\mathrm{ab}$ & 1.5 & efg \\
\hline Halosulfuron & 17.5 & 2 & $a b$ & 1 & $\mathrm{ab}$ & 17.1 & $\mathrm{ab}$ & 1.8 & cdefg \\
\hline Sulfentrazone + s-metolachlor & $140+1050$ & 9 & bcd & 10 & $\mathrm{bcd}$ & 17.3 & $\mathrm{ab}$ & 1.6 & defg \\
\hline Sulfentrazone $+s$-metolachlor & $210+1050$ & 22 & e & 24 & $\mathrm{~d}$ & 17.6 & $\mathrm{~b}$ & 1.5 & efg \\
\hline Halosulfuron + s-metolachlor & $17.5+1050$ & 3 & $a b c$ & 2 & $\mathrm{ab}$ & 17.0 & $\mathrm{ab}$ & 2.5 & $\mathrm{ab}$ \\
\hline Sulfentrazone + halosulfuron & $140+17.5$ & 8 & bcd & 6 & $a b c$ & 17.0 & $\mathrm{ab}$ & 2.0 & bcde \\
\hline Sulfentrazone + halosulfuron & $210+17.5$ & 17 & de & 15 & $\mathrm{~cd}$ & 17.0 & $\mathrm{ab}$ & 1.8 & cdef \\
\hline Sulfentrazone $+s$-metolachlor + halosulfuron & $140+1050+17.5$ & 12 & cde & 10 & bcd & 16.9 & $\mathrm{ab}$ & 2.3 & $a b c$ \\
\hline Sulfentrazone $+s$-metolachlor + halosulfuron & $210+1050+17.5$ & 23 & e & 22 & $\mathrm{~d}$ & 16.9 & $\mathrm{ab}$ & 2.1 & $\mathrm{abcd}$ \\
\hline \multicolumn{2}{|l|}{$\mathrm{SE}( \pm)$} & \multicolumn{2}{|c|}{0.06} & \multicolumn{2}{|c|}{0.06} & \multicolumn{2}{|c|}{0.01} & \multicolumn{2}{|c|}{0.01} \\
\hline
\end{tabular}

${ }^{a}$ Abbreviations: PRE, pre-emergence; WAE, weeks after emergence. Means followed by the same letter within a column are not statistically different according to a Fisher's Protected LSD test at $\alpha=0.05$. Data are averaged for years and locations.

the weeds at the soil surface, placing each species into a separate paper bag, drying in a kiln, and weighing the dry biomass. White bean seed moisture and yield (adjusted to $18 \%$ moisture) were determined at harvest.

\subsection{Statistical Analysis}

Statistical Analysis Software (SAS) version 9.4 (SAS Institute Inc., NC) was used for the analysis. Data were partitioned into fixed and random effects to account for error. Treatments were deemed as fixed effects and their significance determined by the F-test. Replicate, environment, replicate within environment, and environment by treatment interaction were the random effects and their significance was determined using the Z-test. Various transformations of the data were applied using the UNIVARIATE procedure to test the assumptions of normality and homogeneity of the residuals. All transformations met the assumptions for the crop injury, weed control, seed moisture and yield data, therefore the arcsine square root transformation was selected for the analysis as it produced the least amount of error. Weed density and biomass data were transformed using a logarithmic transformation to meet the assumptions. An analysis of variance was performed on all data using the MIXED procedure and Fisher's Protected LSD test $(\alpha=0.05)$. Values were converted back to the original scale for presentation.

\section{Results and Discussion}

\subsection{Crop Injury}

At 2 WAE, sulfentrazone (140 and $210 \mathrm{~g}$ ai ha $\mathrm{h}^{-1}$ ) caused $5 \%$ and $10 \%$ injury in 
white bean, respectively (Table 1). S-metolachlor and halosulfuron caused 2\% injury, and halosulfuron $+s$-metolachlor caused $3 \%$ injury, but were equivalent to the control. The combination of sulfentrazone (140 $\mathrm{g}$ ai ha $\left.{ }^{-1}\right)$ plus s-metolachlor or halosulfuron did not cause greater injury than each herbicide individually, but sulfentrazone (210 $\mathrm{g}$ ai $\mathrm{ha}^{-1}$ ) plus s-metolachlor or halosulfuron caused up to $22 \%$ injury. Similarly, sulfentrazone $\left(140 \mathrm{~g}\right.$ ai ha $\left.{ }^{-1}\right)+\mathrm{s}$-metolachlor + halosulfuron caused $12 \%$ injury, while sulfentrazone $\left(210 \mathrm{~g}\right.$ ai ha $\left.{ }^{-1}\right)+$ s-metolachlor + halosulfuron caused $23 \%$ injury. All tank mixes containing sulfentrazone caused greater injury than the weed-free control. Injury levels at $4 \mathrm{WAE}$ were similar to $2 \mathrm{WAE}$. The level of injury caused by sulfentrazone remained constant at $4 \mathrm{WAE}$, s-metolachlor caused 3\% injury and halosulfuron caused 1\% injury. Soltani et al. [5] also found that halosulfuron (17.5 $\left.\mathrm{g}^{\text {ai ha }}{ }^{-1}\right)$ applied PRE produces very little injury in edible bean. Sulfentrazone $+s$-metolachlor caused up to $24 \%$ injury and sulfentrazone + halosulfuron caused up to $15 \%$ injury. Sulfentrazone $\left(140 \mathrm{~g} \mathrm{a} \mathrm{ha}^{-1}\right)+\mathrm{s}$-metolachlor + halosulfuron caused $10 \%$ injury and sulfentrazone $\left(210 \mathrm{~g}_{\text {ai ha }}{ }^{-1}\right)+\mathrm{s}$-metolachlor + halosulfuron caused $22 \%$ injury. Halosulfuron $+\mathrm{s}$-metolachlor and sulfentrazone $\left(140 \mathrm{~g}^{\mathrm{ai} \mathrm{ha}} \mathrm{h}^{-1}\right)+$ halosulfuron were the only tank mixes at $4 \mathrm{WAE}$ that did not cause injury greater than the weed-free control.

\subsection{Weed Control, Density and Biomass}

\subsubsection{Pigweed Species}

Redroot pigweed and green pigweed (Amaranthus powelli S. Wats.) were the dominant pigweed species at the Exeter and Ridgetown locations, respectively, but were combined for analysis. All herbicides and herbicide combinations provided $\geq 89 \%$ control of pigweeds throughout the season (Table 2). Sulfentrazone (140 and $210 \mathrm{~g}$ ai ha ${ }^{-1}$ ) provided $100 \%$ control at 4 and $8 \mathrm{WAA}$, s-metolachlor provided $89 \%$ control at $4 \mathrm{WAA}$ and $99 \%$ control at $8 \mathrm{WAA}$, and halosulfuron provided $91 \%$ control at $4 \mathrm{WAA}$ and $90 \%$ control at $8 \mathrm{WAA}$. Soltani et al. [4] [5] also found $83 \%$ to $93 \%$ control of redroot pigweed with halosulfuron $(17.5 \mathrm{~g}$ ai $\mathrm{ha}^{-1}$ ) applied PRE. Sulfentrazone (140 and $210 \mathrm{~g}$ ai ha $\left.{ }^{-1}\right)+\mathrm{s}$-metolachlor provided 99 to $100 \%$ control, while sulfentrazone $\left(140 \mathrm{~g}^{\text {ai ha }}{ }^{-1}\right)+$ halosulfuron provided $99 \%$ control at 4 and 8 WAA and sulfentrazone $\left(210 \mathrm{~g}\right.$ ai ha $\left.^{-1}\right)+$ halosulfuron provided $100 \%$ control throughout the season. Sulfentrazone (140 and $\left.210 \mathrm{~g}_{\text {ai }} \mathrm{ha}^{-1}\right)+\mathrm{s}$-metolachlor + halosulfuron provided $98 \%$ to $100 \%$ control. All herbicides and herbicide combinations reduced pigweed density and biomass relative to the weedy control. This level of control is consistent with other studies that used similar rates of sulfentrazone [15] [16].

\subsubsection{Common Ragweed}

At 4 WAA, sulfentrazone at 140 and $210 \mathrm{~g}$ ai ha ${ }^{-1}$ provided $19 \%$ and $24 \%$ control of common ragweed, respectively (Table 3 ). S-metolachlor provided $27 \%$ control, while halosulfuron provided $94 \%$ control and was the only herbicide that provided control equivalent to the weed-free control. Trader et al. [17] reported 
Table 2. Mean visible control, density, and dry biomass of pigweed species (Amaranthus powelli and A. retroflexus) after a PRE application of sulfentrazone, s-metolachlor, halosulfuron, or combination for five field studies conducted near Ridgetown, ON and Exeter, ON, Canada over a two-year period $(2014,2015)^{\mathrm{a}}$.

\begin{tabular}{|c|c|c|c|c|c|c|c|c|c|}
\hline \multirow{3}{*}{\begin{tabular}{|c|} 
Treatment \\
Untreated Control
\end{tabular}} & Rate & \multicolumn{4}{|c|}{ Control (\%) } & \multirow{2}{*}{\multicolumn{2}{|c|}{$\begin{array}{c}\text { Density } 8 \text { WAA } \\
\text { (plants } \mathrm{m}^{-2} \text { ) }\end{array}$}} & \multirow{2}{*}{\multicolumn{2}{|c|}{$\frac{\text { Biomass } 8 \text { WAA }}{\left(\mathrm{g} \cdot \mathrm{m}^{-2}\right)}$}} \\
\hline & \multirow[t]{2}{*}{$\left(\mathrm{g}_{\text {ai ha }}{ }^{-1}\right)$} & \multicolumn{2}{|c|}{$4 \mathrm{WAA}$} & \multicolumn{2}{|c|}{$8 \mathrm{WAA}$} & & & & \\
\hline & & 0 & $\mathrm{~b}$ & \multicolumn{2}{|c|}{$0 \quad \mathrm{~b}$} & 7.0 & $\mathrm{~b}$ & 4.5 & $\mathrm{~b}$ \\
\hline Weed-free Control & & 100 & a & 100 & a & 0.0 & $\mathrm{a}$ & 0.0 & a \\
\hline S-metolachlor & 1050 & 89 & a & 99 & a & 0.4 & a & 0.5 & a \\
\hline Sulfentrazone & 140 & 100 & a & 100 & a & 0.3 & a & 0.3 & a \\
\hline Sulfentrazone & 210 & 100 & $\mathrm{a}$ & 100 & $\mathrm{a}$ & 0.0 & a & 0.0 & a \\
\hline Halosulfuron & 17.5 & 91 & a & 90 & a & 0.6 & a & 0.4 & a \\
\hline Sulfentrazone + s-metolachlor & $140+1050$ & 100 & a & 99 & a & 0.1 & a & 0.2 & a \\
\hline Sulfentrazone $+s$-metolachlor & $210+1050$ & 100 & a & 100 & a & 0.0 & a & 0.0 & a \\
\hline Halosulfuron + s-metolachlor & $17.5+1050$ & 98 & $\mathrm{a}$ & 98 & a & 0.3 & a & 0.5 & a \\
\hline Sulfentrazone + halosulfuron & $140+17.5$ & 99 & a & 99 & a & 0.1 & a & 0.1 & a \\
\hline Sulfentrazone + halosulfuron & $210+17.5$ & 100 & $\mathrm{a}$ & 100 & $a$ & 0.2 & a & 0.2 & a \\
\hline Sulfentrazone + s-metolachlor + halosulfuron & $140+1050+17.5$ & 100 & $a$ & 98 & a & 0.0 & a & 0.0 & a \\
\hline Sulfentrazone + s-metolachlor + halosulfuron & $210+1050+17.5$ & 100 & a & 100 & $\mathrm{a}$ & 0.0 & a & 0.0 & a \\
\hline $\operatorname{SE}( \pm)$ & & & & & & & & & \\
\hline
\end{tabular}

${ }^{a}$ Abbreviations: PRE, pre-emergence; WAA, weeks after application. Means followed by the same letter within a column are not statistically different according to a Fisher's Protected LSD test at $\alpha=0.05$. Data are averaged for years and locations.

Table 3. Mean visible control, density, and dry biomass of common ragweed (Ambrosia artemisiifolia) after a PRE application of sulfentrazone, s-metolachlor, halosulfuron, or combination for five field studies conducted near Ridgetown, ON and Exeter, ON, Canada over a two-year period $(2014,2015)^{\mathrm{a}}$.

\begin{tabular}{|c|c|c|c|c|c|c|c|c|c|}
\hline \multirow{3}{*}{$\begin{array}{c}\text { Treatment } \\
\text { Untreated Control }\end{array}$} & \multirow{3}{*}{$\frac{\text { Rate }}{\left(\mathrm{g}^{\mathrm{ai} \mathrm{ha}} \mathrm{ha}^{-1}\right)}$} & \multicolumn{4}{|c|}{ Control (\%) } & \multirow{2}{*}{\multicolumn{2}{|c|}{$\begin{array}{c}\text { Density } 8 \text { WAA } \\
\text { (plants } \mathrm{m}^{-2} \text { ) }\end{array}$}} & \multirow{2}{*}{\multicolumn{2}{|c|}{$\frac{\text { Biomass } 8 \text { WAA }}{\left(\mathrm{g} \cdot \mathrm{m}^{-2}\right)}$}} \\
\hline & & \multicolumn{2}{|c|}{ 4 WAA } & \multicolumn{2}{|c|}{$8 \mathrm{WAA}$} & & & & \\
\hline & & 0 & $\mathrm{~b}$ & 0 & $\mathrm{c}$ & 7.5 & $\mathrm{~d}$ & 11.1 & bcd \\
\hline Weed-free Control & & 100 & $\mathrm{a}$ & 100 & $\mathrm{a}$ & 0.2 & $\mathrm{a}$ & 0.3 & $\mathrm{a}$ \\
\hline S-metolachlor & 1050 & 27 & $\mathrm{~b}$ & 7 & $c$ & 4.5 & bcd & 10.6 & bcd \\
\hline Sulfentrazone & 140 & 19 & $\mathrm{~b}$ & 11 & $\mathrm{c}$ & 6.3 & $\mathrm{~cd}$ & 15.9 & $\mathrm{~cd}$ \\
\hline Sulfentrazone & 210 & 24 & $\mathrm{~b}$ & 16 & c & 5.4 & bcd & 15.0 & $\mathrm{~cd}$ \\
\hline Halosulfuron & 17.5 & 94 & $\mathrm{a}$ & 83 & $\mathrm{a}$ & 1.5 & abcd & 2.3 & $a b c$ \\
\hline Sulfentrazone + s-metolachlor & $140+1050$ & 12 & $\mathrm{~b}$ & 7 & c & 6.0 & $\mathrm{~cd}$ & 15.4 & $\mathrm{~cd}$ \\
\hline Sulfentrazone + s-metolachlor & $210+1050$ & 26 & $\mathrm{~b}$ & 18 & $\mathrm{bc}$ & 5.6 & bcd & 19.5 & $\mathrm{~d}$ \\
\hline Halosulfuron + s-metolachlor & $17.5+1050$ & 98 & $\mathrm{a}$ & 90 & a & 1.2 & abcd & 1.6 & $\mathrm{ab}$ \\
\hline Sulfentrazone + halosulfuron & $140+17.5$ & 86 & $\mathrm{a}$ & 75 & $\mathrm{ab}$ & 1.3 & abcd & 2.9 & abcd \\
\hline Sulfentrazone + halosulfuron & $210+17.5$ & 90 & $\mathrm{a}$ & 77 & a & 1.7 & abcd & 1.8 & $\mathrm{abc}$ \\
\hline Sulfentrazone $+s$-metolachlor + halosulfuron & $140+1050+17.5$ & 94 & $\mathrm{a}$ & 90 & a & 0.7 & $\mathrm{ab}$ & 0.7 & $\mathrm{a}$ \\
\hline Sulfentrazone + s-metolachlor + halosulfuron & $210+1050+17.5$ & 98 & $\mathrm{a}$ & 94 & a & 0.8 & $\mathrm{abc}$ & 1.4 & $\mathrm{ab}$ \\
\hline \multicolumn{2}{|l|}{$\mathrm{SE}( \pm)$} & \multicolumn{2}{|c|}{0.16} & \multicolumn{2}{|c|}{0.18} & \multicolumn{2}{|c|}{0.54} & \multicolumn{2}{|c|}{0.65} \\
\hline
\end{tabular}

${ }^{a}$ Abbreviations: PRE, pre-emergence; WAA, weeks after application. Means followed by the same letter within a column are not statistically different according to a Fisher's Protected LSD test at $\alpha=0.05$. Data are averaged for years and locations.

up to $97 \%$ control of common ragweed in pumpkin with $18 \mathrm{~g}$ ai ha $\mathrm{h}^{-1}$ halosulfuron. Sulfentrazone (140 and $210 \mathrm{~g}$ ai ha $^{-1}$ ) + s-metolachlor provided up to $26 \%$ control, and was not improved compared to either herbicide applied alone. In 
contrast, sulfentrazone (140 and $210 \mathrm{~g}$ ai ha $\left.{ }^{-1}\right)+$ halosulfuron provided $86 \%$ and $90 \%$ control, respectively, which was equivalent to the weed-free control and an improvement compared to sulfentrazone applied alone. Similarly, sulfentrazone $\left(140\right.$ and $210 \mathrm{~g}$ ai $\left.\mathrm{ha}^{-1}\right)+\mathrm{s}$-metolachlor + halosulfuron provided $94 \%$ to $98 \%$ control and were equivalent to the weed-free control. Soltani et al. [8] also found good control of common ragweed with halosulfuron tank mixes applied preplant incorporated. At $8 \mathrm{WAA}$, control decreased with all herbicides and herbicide combinations. Sulfentrazone (140 and $210 \mathrm{~g}_{\text {ai }} \mathrm{ha}^{-1}$ ), s-metolachlor and sulfentrazone $+\mathrm{s}$-metolachlor provided up to $18 \%$ control and were not different from the weedy control. In contrast, halosulfuron provided $83 \%$ control, sulfentrazone + halosulfuron provided $75 \%$ to $77 \%$ control, and sulfentrazone $\left(140\right.$ and $210 \mathrm{~g}$ ai ha $\left.{ }^{-1}\right)+$ s-metolachlor + halosulfuron provided $90 \%$ to $94 \%$ control, and were equivalent to the weed-free control. Sulfentrazone (140 and $210 \mathrm{~g}_{\text {ai ha }}{ }^{-1}$ ) reduced ragweed density by $16 \%$ and $28 \%$, respectively, and sulfentrazone $+\mathrm{s}$-metolachlor reduced density by up to $25 \%$. Sulfentrazone + halosulfuron tank mixes reduced density by up to $83 \%$, but were not statistically different from the weedy control. Sulfentrazone (140 and $210 \mathrm{~g}$ ai ha $\left.{ }^{-1}\right)+\mathrm{s}$-metolachlor + halosulfuron reduced ragweed density by 89 and $91 \%$, respectively, and were the only herbicide treatments that reduced density relative to the weedy control. None of the herbicides applied on their own reduced ragweed biomass relative to the weedy control. Sulfentrazone $+s$-metolachlor did not provide any biomass reduction, while sulfentrazone (140 and $210 \mathrm{~g}$ ai ha $\left.^{-1}\right)+$ halosulfuron reduced ragweed biomass by $74 \%$ and $84 \%$, respectively, but was not an improvement compared to the weedy control. Sulfentrazone $\left(210 \mathrm{~g}^{\mathrm{ai} \mathrm{ha}} \mathrm{ha}^{-1}\right)+$ s-metolachlor + halosulfuron also reduced biomass by $87 \%$, but was not different from the weedy control. Sulfentrazone $\left(140 \mathrm{~g}\right.$ i ha $\left.{ }^{-1}\right)+\mathrm{s}$-metolachlor + halosulfuron was the only herbicide treatment that reduced ragweed biomass relative to the weedy control, providing a $94 \%$ reduction.

\subsubsection{Common Lambsquarters}

Sulfentrazone ( 140 and $210 \mathrm{~g}^{\text {ai ha }} \mathrm{h}^{-1}$ ) provided $100 \%$ control of common lambsquarters at 4 and $8 \mathrm{WAA}$ (Table 4). S-metolachlor provided 7\% control at 4 WAA and $16 \%$ control at 8 WAA, while halosulfuron provided $87 \%$ to $97 \%$ control. This is consistent with another study which found $83 \%$ to $96 \%$ control of common lambsquarters with the same rate of halosulfuron [5]. Sulfentrazone + s-metolachlor and sulfentrazone + halosulfuron provided $99 \%$ to $100 \%$ control at 4 and $8 \mathrm{WAA}$, while the three-way tank mixes provided $100 \%$ control. Sulfentrazone (140 and $210 \mathrm{~g}$ ai ha $^{-1}$ ) reduced lambsquarters density by $100 \%$, s-metolachlor reduced density by $67 \%$, and halosulfuron reduced density by $82 \%$. Sulfentrazone + s-metolachlor reduced density by $100 \%$, and sulfentrazone + halosulfuron reduced density by $99 \%$ to $100 \%$. Both three-way tank mixes reduced density by $100 \%$. Sulfentrazone applied alone and in a co-application reduced lambsquarters density to an equivalent level as the weed-free control. Similarly, sulfentrazone (140 and $210 \mathrm{~g}^{\text {ai ha }} \mathrm{h}^{-1}$ ), s-metolachlor and halosulfuron 
Table 4. Mean visible control, density, and dry biomass of common lambsquarters (Chenopodium album) after a PRE application of sulfentrazone, s-metolachlor, halosulfuron, or combination for five field studies conducted near Ridgetown, ON and Exeter, ON, Canada over a two-year period $(2014,2015)^{\mathrm{a}}$.

\begin{tabular}{|c|c|c|c|c|c|c|c|c|c|}
\hline \multirow{3}{*}{$\begin{array}{cc}\text { Treatment } \\
\text { Untreated Control }\end{array}$} & \multirow{3}{*}{$\frac{\text { Rate }}{\left(\mathrm{g}_{\mathrm{ai} \mathrm{ha}}^{-1}\right)}$} & \multicolumn{4}{|c|}{ Control (\%) } & \multirow{2}{*}{\multicolumn{2}{|c|}{$\begin{array}{c}\text { Density } 8 \text { WAA } \\
\left(\text { plants } \mathrm{m}^{-2}\right)\end{array}$}} & \multirow{2}{*}{\multicolumn{2}{|c|}{$\frac{\text { Biomass } 8 \text { WAA }}{\left(\mathrm{g} \cdot \mathrm{m}^{-2}\right)}$}} \\
\hline & & \multicolumn{2}{|c|}{$4 \mathrm{WAA}$} & \multicolumn{2}{|c|}{8 WAA } & & & & \\
\hline & & 0 & $\mathrm{~b}$ & 0 & $\mathrm{c}$ & 13.9 & $\mathrm{~d}$ & 7.1 & $\mathrm{~b}$ \\
\hline Weed-free Control & & 100 & a & 100 & $\mathrm{a}$ & 0.2 & $\mathrm{a}$ & 0.2 & a \\
\hline S-metolachlor & 1050 & 7 & $\mathrm{~b}$ & 16 & $\mathrm{c}$ & 4.6 & c & 5.8 & $\mathrm{~b}$ \\
\hline Sulfentrazone & 140 & 100 & a & 100 & $\mathrm{a}$ & 0.0 & $\mathrm{a}$ & 0.0 & a \\
\hline Sulfentrazone & 210 & 100 & $\mathrm{a}$ & 100 & $\mathrm{a}$ & 0.0 & $\mathrm{a}$ & 0.0 & a \\
\hline Halosulfuron & 17.5 & 87 & $\mathrm{a}$ & 97 & $\mathrm{ab}$ & 2.5 & $\mathrm{bc}$ & 0.4 & a \\
\hline Sulfentrazone + s-metolachlor & $140+1050$ & 100 & a & 99 & $a b$ & 0.0 & $\mathrm{a}$ & 0.0 & a \\
\hline Sulfentrazone + s-metolachlor & $210+1050$ & 100 & a & 100 & $\mathrm{a}$ & 0.0 & $\mathrm{a}$ & 0.0 & a \\
\hline Halosulfuron + s-metolachlor & $17.5+1050$ & 91 & a & 76 & $\mathrm{~b}$ & 1.0 & $\mathrm{ab}$ & 0.6 & a \\
\hline Sulfentrazone + halosulfuron & $140+17.5$ & 99 & a & 99 & $\mathrm{ab}$ & 0.1 & a & 0.2 & a \\
\hline Sulfentrazone + halosulfuron & $210+17.5$ & 100 & a & 99 & $\mathrm{ab}$ & 0.0 & $\mathrm{a}$ & 0.0 & a \\
\hline Sulfentrazone $+s$-metolachlor + halosulfuron & $140+1050+17.5$ & 100 & a & 100 & $\mathrm{ab}$ & 0.0 & $\mathrm{a}$ & 0.0 & a \\
\hline Sulfentrazone $+s$-metolachlor + halosulfuron & $210+1050+17.5$ & 100 & a & 100 & $\mathrm{a}$ & 0.0 & $\mathrm{a}$ & 0.0 & a \\
\hline \multicolumn{2}{|l|}{$\mathrm{SE}( \pm)$} & \multicolumn{2}{|c|}{0.09} & \multicolumn{2}{|c|}{0.11} & \multicolumn{2}{|c|}{0.17} & \multicolumn{2}{|c|}{0.17} \\
\hline
\end{tabular}

${ }^{a}$ Abbreviations: PRE, pre-emergence; WAA, weeks after application. Means followed by the same letter within a column are not statistically different according to a Fisher's Protected LSD test at $\alpha=0.05$. Data are averaged for years and locations.

reduced lambsquarters biomass by $100 \%, 100 \%, 18 \%$ and $94 \%$, respectively. Sulfentrazone + s-metolachlor provided a $100 \%$ reduction, sulfentrazone + halosulfuron provided 97 to $100 \%$ reduction in biomass, and sulfentrazone (140 and $210 \mathrm{~g}_{\text {ai }} \mathrm{ha}^{-1}$ ) $+\mathrm{s}$-metolachlor + halosulfuron reduced biomass by $100 \%$. Sulfentrazone has shown excellent control of common lambsquarters when used alone and in a tank mix [18] [19].

\subsubsection{Wild Mustard}

Sulfentrazone (140 and $210 \mathrm{~g}$ ai ha ${ }^{-1}$ ), s-metolachlor, and halosulfuron provided $50 \%, 48 \%, 20 \%$ and $100 \%$ control of wild mustard, respectively, at 4 WAA (Table 5). Excellent control of wild mustard with halosulfuron has been noted in other studies [4] [5]. Control decreased to $5 \%, 12 \%$, and $2 \%$ for sulfentrazone

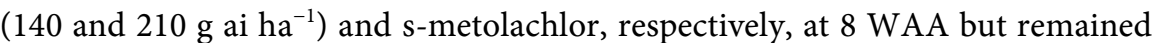
constant for halosulfuron. Sulfentrazone $\left(140 \mathrm{~g}^{\mathrm{ai}} \mathrm{ha}^{-1}\right)+\mathrm{s}$-metolachlor provided $54 \%$ control at $4 \mathrm{WAA}$, which was not an improvement compared to sulfentrazone alone, and decreased to $1 \%$ control by 8 WAA. In contrast, sulfentrazone $\left(210 \mathrm{~g}\right.$ ai ha $\left.^{-1}\right)+\mathrm{s}$-metolachlor provided $87 \%$ control at $4 \mathrm{WAA}$ and was an improvement compared to sulfentrazone, but decreased to $20 \%$ control at 8 WAA. Sulfentrazone + halosulfuron and sulfentrazone (140 and $210 \mathrm{~g}$ ai ha ${ }^{-1}$ ) + s-metolachlor + halosulfuron provided $100 \%$ control at both 4 and 8 WAA. Sulfentrazone alone reduced wild mustard density by $67 \%$, and s-metolachlor reduced density by $49 \%$, but neither herbicide reduced density relative to the 
Table 5. Mean visible control, density, and dry biomass of wild mustard (Sinapis arvensis) after a PRE application of sulfentrazone, s-metolachlor, halosulfuron, or combination for five field studies conducted near Ridgetown, ON and Exeter, ON, Canada over a two-year period $(2014,2015)^{\mathrm{a}}$.

\begin{tabular}{|c|c|c|c|c|c|c|c|c|c|}
\hline \multirow{3}{*}{$\begin{array}{c}\text { Treatment } \\
\text { Untreated Control }\end{array}$} & \multirow{3}{*}{$\frac{\text { Rate }}{\left(\mathrm{g} \mathrm{ai} \mathrm{ha}^{-1}\right)}$} & \multicolumn{4}{|c|}{ Control (\%) } & \multirow{2}{*}{\multicolumn{2}{|c|}{$\begin{array}{c}\text { Density } 8 \text { WAA } \\
\text { (plants } \mathrm{m}^{-2} \text { ) }\end{array}$}} & \multirow{2}{*}{\multicolumn{2}{|c|}{$\frac{\text { Biomass } 8 \text { WAA }}{\left(\mathrm{g} \cdot \mathrm{m}^{-2}\right)}$}} \\
\hline & & \multicolumn{2}{|c|}{$4 \mathrm{WAA}$} & \multicolumn{2}{|c|}{$8 \mathrm{WAA}$} & & & & \\
\hline & & 0 & e & 0 & c & 31.0 & c & 93.6 & $\mathrm{~b}$ \\
\hline Weed-free Control & & 100 & $\mathrm{a}$ & 100 & a & 0.0 & a & 0.0 & $\mathrm{a}$ \\
\hline S-metolachlor & 1050 & 20 & $\mathrm{~d}$ & 2 & $\mathrm{bc}$ & 15.9 & $\mathrm{bc}$ & 51.8 & $\mathrm{~b}$ \\
\hline Sulfentrazone & 140 & 50 & $\mathrm{~cd}$ & 5 & $\mathrm{bc}$ & 10.3 & $\mathrm{bc}$ & 37.1 & $\mathrm{~b}$ \\
\hline Sulfentrazone & 210 & 48 & $\mathrm{~cd}$ & 12 & $\mathrm{bc}$ & 10.3 & $\mathrm{bc}$ & 32.1 & $\mathrm{~b}$ \\
\hline Halosulfuron & 17.5 & 100 & $\mathrm{ab}$ & 100 & a & 0.0 & a & 0.0 & a \\
\hline Sulfentrazone $+s$-metolachlor & $140+1050$ & 54 & c & 1 & $\mathrm{bc}$ & 10.5 & $\mathrm{bc}$ & 51.7 & $\mathrm{~b}$ \\
\hline Sulfentrazone $+s$-metolachlor & $210+1050$ & 87 & $\mathrm{~b}$ & 20 & $\mathrm{~b}$ & 5.3 & $\mathrm{~b}$ & 14.8 & $\mathrm{~b}$ \\
\hline Halosulfuron + s-metolachlor & $17.5+1050$ & 100 & $\mathrm{a}$ & 100 & a & 0.0 & a & 0.0 & $\mathrm{a}$ \\
\hline Sulfentrazone + halosulfuron & $140+17.5$ & 100 & $\mathrm{a}$ & 100 & a & 0.0 & a & 0.0 & $\mathrm{a}$ \\
\hline Sulfentrazone + halosulfuron & $210+17.5$ & 100 & a & 100 & a & 0.1 & a & 0.0 & a \\
\hline Sulfentrazone $+s$-metolachlor + halosulfuron & $140+1050+17.5$ & 100 & $\mathrm{a}$ & 100 & a & 0.0 & a & 0.0 & $\mathrm{a}$ \\
\hline Sulfentrazone $+s$-metolachlor + halosulfuron & $210+1050+17.5$ & 100 & a & 100 & a & 0.0 & a & 0.0 & $\mathrm{a}$ \\
\hline \multicolumn{2}{|l|}{$\mathrm{SE}( \pm)$} & \multicolumn{2}{|c|}{0.07} & \multicolumn{2}{|c|}{0.09} & \multicolumn{2}{|c|}{0.28} & \multicolumn{2}{|c|}{0.45} \\
\hline
\end{tabular}

${ }^{a}$ Abbreviations: PRE, pre-emergence; WAA, weeks after application. Means followed by the same letter within a column are not statistically different according to a Fisher's Protected LSD test at $\alpha=0.05$. Data are averaged for years and locations.

weedy control. Sulfentrazone $\left(140 \mathrm{~g}\right.$ ai ha $\left.{ }^{-1}\right)+\mathrm{s}$-metolachlor also did not reduce density relative to the control, but sulfentrazone $\left(210 \mathrm{~g}_{\text {ai ha }}{ }^{-1}\right)+\mathrm{s}$-metolachlor significantly reduced density by $83 \%$. Similarly, sulfentrazone reduced wild mustard biomass by up to $66 \%$, s-metolachlor reduced biomass by $45 \%$, and sulfentrazone $+s$-metolachlor reduced biomass by up to $84 \%$, but none were different from the weedy control. In contrast, halosulfuron and all co-applications containing halosulfuron reduced density and biomass equivalent to the weed-free control.

\subsubsection{Green Foxtail}

At 4 WAA, sulfentrazone ( 140 and $210 \mathrm{~g}$ ai ha ${ }^{-1}$ ) provided $68 \%$ and $84 \%$ control of green foxtail (Setaria viridis (L.) Beauv), respectively, s-metolachlor provided $99 \%$ control and halosulfuron provided $31 \%$ control (Table 6). Sulfentrazone at either rate combined with s-metolachlor provided $99 \%$ control. Sulfentrazone (140 and $210 \mathrm{~g}$ ai ha $^{-1}$ ) plus halosulfuron provided $67 \%$ and $85 \%$ control, respectively, and were not an improvement compared to sulfentrazone applied alone. Sulfentrazone + s-metolachlor + halosulfuron provided $98 \%$ to $99 \%$ control. At 8 WAA, green foxtail control with sulfentrazone (140 and $210 \mathrm{~g}$ ai ha ${ }^{-1}$ ) decreased to $45 \%$ and $80 \%$ control, respectively, control with s-metolachlor remained constant, and control with halosulfuron decreased to $11 \%$ and was not different from the weedy control. Sulfentrazone $+\mathrm{s}$-metolachlor provided 98 to $99 \%$ control, while sulfentrazone + halosulfuron provided $42 \%$ to $63 \%$ control. The co-application of sulfentrazone + halosulfuron was not an improvement 
Table 6. Mean visible control, density, and dry biomass of green foxtail (Setaria viridis) after a PRE application of sulfentrazone, s-metolachlor, halosulfuron, or combination, for five field studies conducted near Ridgetown, ON and Exeter, ON, Canada over a two-year period $(2014,2015)^{\mathrm{a}}$.

\begin{tabular}{|c|c|c|c|c|c|c|c|c|c|}
\hline \multirow{3}{*}{$\begin{array}{c}\text { Treatment } \\
\text { Untreated Control }\end{array}$} & \multirow{3}{*}{$\frac{\text { Rate }}{\left(\mathrm{g}_{\mathrm{ai} \mathrm{ha}} \mathrm{h}^{-1}\right)}$} & \multicolumn{4}{|c|}{ Control (\%) } & \multirow{2}{*}{\multicolumn{2}{|c|}{$\begin{array}{c}\text { Density } 8 \text { WAA } \\
\text { (plants } \mathrm{m}^{-2} \text { ) }\end{array}$}} & \multirow{2}{*}{\multicolumn{2}{|c|}{$\frac{\text { Biomass } 8 \text { WAA }}{\left(\mathrm{g} \cdot \mathrm{m}^{-2}\right)}$}} \\
\hline & & \multicolumn{2}{|c|}{$4 \mathrm{WAA}$} & \multicolumn{2}{|c|}{$8 \mathrm{WAA}$} & & & & \\
\hline & & 0 & $\mathrm{~d}$ & 0 & $\mathrm{f}$ & 87.3 & $\mathrm{f}$ & 42.4 & g \\
\hline Weed-free Control & & 100 & a & 100 & a & 0.0 & $\mathrm{a}$ & 0.0 & a \\
\hline S-metolachlor & 1050 & 99 & $\mathrm{a}$ & 99 & $\mathrm{ab}$ & 1.8 & $\mathrm{abc}$ & 0.7 & $\mathrm{ab}$ \\
\hline Sulfentrazone & 140 & 68 & $\mathrm{~b}$ & 45 & de & 20.1 & def & 7.8 & def \\
\hline Sulfentrazone & 210 & 84 & $\mathrm{~b}$ & 80 & bcd & 8.3 & bcde & 4.4 & bcde \\
\hline Halosulfuron & 17.5 & 31 & c & 11 & ef & 48.7 & ef & 20.3 & fg \\
\hline Sulfentrazone $+s$-metolachlor & $140+1050$ & 99 & $\mathrm{a}$ & 98 & $\mathrm{ab}$ & 1.6 & $\mathrm{abc}$ & 0.6 & $\mathrm{ab}$ \\
\hline Sulfentrazone $+s$-metolachlor & $210+1050$ & 99 & a & 99 & $\mathrm{ab}$ & 0.8 & $\mathrm{ab}$ & 0.4 & a \\
\hline Halosulfuron $+s$-metolachlor & $17.5+1050$ & 98 & a & 96 & $\mathrm{ab}$ & 3.5 & abcd & 1.5 & abcd \\
\hline Sulfentrazone + halosulfuron & $140+17.5$ & 67 & $\mathrm{~b}$ & 42 & de & 26.3 & def & 10.8 & efg \\
\hline Sulfentrazone + halosulfuron & $210+17.5$ & 85 & $\mathrm{~b}$ & 63 & $\mathrm{~cd}$ & 11.9 & cde & 5.7 & cdef \\
\hline Sulfentrazone $+s$-metolachlor + halosulfuron & $140+1050+17.5$ & 98 & a & 95 & $a b c$ & 1.1 & $\mathrm{abc}$ & 0.8 & $\mathrm{ab}$ \\
\hline Sulfentrazone + s-metolachlor + halosulfuron & $210+1050+17.5$ & 99 & a & 98 & $\mathrm{ab}$ & 1.3 & $\mathrm{abc}$ & 0.8 & $a b c$ \\
\hline \multicolumn{2}{|l|}{$\mathrm{SE}( \pm)$} & \multicolumn{2}{|c|}{0.07} & \multicolumn{2}{|c|}{0.12} & \multicolumn{2}{|c|}{0.56} & \multicolumn{2}{|c|}{0.49} \\
\hline
\end{tabular}

a Abbreviations: PRE, pre-emergence; WAA, weeks after application. Means followed by the same letter within a column are not statistically different according to a Fisher's Protected LSD test at $\alpha=0.05$. Data are averaged for years and locations.

relative to sulfentrazone on its own, but did provide control relative to the weedy control. Sulfentrazone (140 and $\left.210 \mathrm{~g}_{\text {ai ha }} \mathrm{ha}^{-1}\right)+\mathrm{s}$-metolachlor + halosulfuron provided $95 \%$ to $98 \%$ control and were equivalent to the weed-free control. Other studies have shown improved control of foxtail species when either sulfentrazone or halosulfuron were tank mixed with a grass herbicide [4] [10]. Sulfentrazone $\left(140 \mathrm{~g}_{\text {ai }} \mathrm{ha}^{-1}\right)$ reduced green foxtail density by $77 \%$, which was not different from the weedy control, while sulfentrazone $\left(210 \mathrm{~g}\right.$ ai ha $\left.{ }^{-1}\right)$ reduced density by $90 \%$. S-metolachlor reduced density by $98 \%$ and halosulfuron reduced density by $44 \%$. Sulfentrazone at either rate plus s-metolachlor reduced foxtail density by up to $99 \%$, and was equivalent to the weed-free control. In contrast, sulfentrazone $\left(140 \mathrm{~g}_{\text {ai ha }} \mathrm{h}^{-1}\right)+$ halosulfuron provided only a $70 \%$ reduction and was not an improvement relative to the weedy control. Sulfentrazone $\left(210 \mathrm{~g}_{\text {ai }} \mathrm{ha}^{-1}\right)$ reduced density relative to the weedy control, but was not an improvement compared to either herbicide on its own. Sulfentrazone + s-metolachlor + halosulfuron provided up to $99 \%$ density reduction. Sulfentrazone (140 and $210 \mathrm{~g}$ ai $\mathrm{ha}^{-1}$ ) reduced green foxtail biomass by up to $90 \%$, s-metolachlor reduced biomass by $98 \%$, and halosulfuron reduced biomass by $52 \%$ but not relative to the weedy control. Sulfentrazone $+s$-metolachlor and sulfentrazone $+s$-metolachlor + halosulfuron reduced green foxtail biomass by $99 \%$ and $98 \%$, respectively, and were equivalent to the weed-free control. Sulfentrazone $\left(140 \mathrm{~g}_{\text {ai }} \mathrm{ha}^{-1}\right)+$ halosulfuron did not reduce green foxtail biomass relative to the weedy control, while sulfentrazone $\left(210 \mathrm{~g}\right.$ ai ha $\left.{ }^{-1}\right)+$ halosulfuron 
reduced biomass by $87 \%$.

\subsection{Seed Moisture Content and Yield}

Seed moisture at harvest ranged between $16.8 \%$ and $17.6 \%$ (Table 1). Sulfentrazone $\left(210 \mathrm{~g}_{\text {ai }} \mathrm{ha}^{-1}\right)+\mathrm{s}$-metolachlor had a higher moisture content than the weed-free control, which could be due to the high level of injury produced by this tank mix causing delayed maturity. All other herbicide treatments had a moisture content equivalent to the weed-free control. White bean yield ranged from 1.2 to $2.7 \mathrm{~T} \mathrm{ha}^{-1}$. Comparing the two controls, weed interference in this study caused a $56 \%$ yield loss. Sulfentrazone (140 and $210 \mathrm{~g}$ ai ha ${ }^{-1}$ ), s-metolachlor, and halosulfuron produced yields that were $52 \%, 44 \%, 44 \%$, and $33 \%$ lower than the weed-free control, respectively, and were not different from the weedy control. This yield loss is likely attributed to weed interference rather than crop injury, as injury levels for these treatments were relatively low. Sulfentrazone $+\mathrm{s}$-metolachlor did not improve yield relative to either herbicide on its own or to the weedy control. In contrast, sulfentrazone (140 and $210 \mathrm{~g}$ ai ha $\left.{ }^{-1}\right)+$ halosulfuron produced yields greater than the weedy control, at $2.0 \mathrm{~T} \mathrm{ha}^{-1}$ and $1.8 \mathrm{~T} \mathrm{ha}^{-1}$, respectively. Sulfentrazone $\left(140 \mathrm{~g}\right.$ ai ha $\left.{ }^{-1}\right)+$ halosulfuron improved yield compared to sulfentrazone alone, but sulfentrazone $\left(210 \mathrm{~g}\right.$ ai ha $\left.{ }^{-1}\right)+$ halosulfuron did not. Sulfentrazone $+s$-metolachlor + halosulfuron produced yields that were equivalent to the weed-free control, likely attributed to better weed control as crop injury was as high as $23 \%$.

\section{Conclusion}

In this study, sulfentrazone applied PRE provided excellent control of redroot/ green pigweed and common lambsquarters. When a low rate of halosulfuron was added to sulfentrazone, the spectrum of broadleaf weed control was improved. Sulfentrazone + halosulfuron provided good to excellent control of pigweeds, common lambsquarters, common ragweed, and wild mustard. Sulfentrazone + s-metolachlor + halosulfuron also provided excellent control of these species as well as green foxtail, but did not have an adequate margin of crop safety, therefore this study does not support the use of a tank mix of sulfentrazone + s-metolachlor + halosulfuron in Ontario white bean. However, this tank mix does provide broad spectrum weed control, and should be examined in other market classes of dry bean to determine their tolerance to the co-application of these three herbicides.

\section{References}

[1] Kulasekera, K. (2015) Estimated Area, Yield, Production and Farm Value of Specified Field Crops, Ontario, 2011-2015. Ontario Ministry of Agriculture, Food and Rural Affairs, Ontario. http://www.omafra.gov.on.ca/english/stats/crops/estimate_new.htm\#metric

[2] Statistics Canada (2015) Estimated Areas, Yield, Production and Average Farm Price of Principal Field Crops, in Metric Units, Annual, CANSIM (Database). http://www5.statcan.gc.ca/cansim/a26?lang=eng\&id=10010 
[3] Ghamari, H. and Ahmadvand, G. (2012) Weed Interference Affects Dry Bean Yield and Growth. Notulae Scientia Biologicae, 4, 70-75.

[4] Soltani, N., Nurse, R.E., Shropshire, C. and Sikkema, P.H. (2014) Weed Control in White Bean with Various Halosulfuron Tankmixes. Advances in Agriculture, 2014, Article ID: 391634. https://doi.org/10.1155/2014/391634

[5] Soltani, N., Nurse, R.E., Shropshire, C. and Sikkema, P.H. (2014) Weed Control with Halosulfuron Applied Preplant Incorporated, Preemergence or Postemergence in White Bean. Agricultural Sciences, 5, 875-881.

https://doi.org/10.4236/as.2014.510094

[6] Malik, V.S., Swanton, C.J. and Michaels, T.E. (1993) Interaction of White Bean (Phaseolus vulgaris) Cultivars, Row Spacing, and Seeding Density with Annual Weeds. Weed Science, 41, 62-68.

[7] Hancock, H.G. (2001) Sulfentrazone North American Field Performance: A Review in Efficacy in Selected Crops and Identification of Potential Partner Herbicides. FMC Corporation, Philadelphia, $152 \mathrm{p}$.

[8] Shaner, D.L. (2014) Herbicide Handbook. 10th Edition, Weed Science Society of America, Champaign, 513.

[9] Niekamp, J.W., Johnson, W.G. and Smeda, R.J. (1999) Broadleaf Weed Control with Sulfentrazone and Flumioxazin in No-Tillage Soybean (Glycine max). Weed Technology, 13, 233-238.

[10] Niekamp, J.W. and Johnson, W.G. (2001) Weed Management with Sulfentrazone and Flumioxazin in No-Tillage Soyabean (Glycine max). Crop Protection, 20, 215220. https://doi.org/10.1016/S0261-2194(00)00129-0

[11] Anonymous (2012) Authority 480 Herbicide. FMC Corporation, Philadelphia, 4 p.

[12] Anonymoust (2014) Permit Herbicide. Gowan Canada, Yuma, 19 p.

[13] Heap, I. (2014) The International Survey of Herbicide Resistant Weeds. http://weedscience.org/summary/country.aspx

[14] Ontario Ministry of Agriculture, Food and Rural Affairs (OMAFRA) (2014) Guide to Weed Control. Publication 75, Toronto, 425.

[15] Walsh, K.D., Soltani, N., Hooker, D.C., Nurse, R.E. and Sikkema, P.H. (2015) Biologically Effective Rate of Sulfentrazone Applied Pre-Emergence in Soybean. Canadian Journal of Plant Science, 95, 1-6. https://doi.org/10.4141/cjps-2014-264

[16] Wilson, D.E., Nissen, S.J. and Thompson, A. (2002) Potato (Solanum tuberosum) Variety and Weed Response to Sulfentrazone and Flumioxazin. Weed Technology, 16, 567-574. https://doi.org/10.1614/0890-037X(2002)016[0567:PSTVAW]2.0.CO;2

[17] Trader, B.W., Wilson, H.P. and Hines, T.E. (2007) Halosulfuron Helps Control Several Broadleaf Weeds in Cucumber and Pumpkin. Weed Technology, 21, 966971. https://doi.org/10.1614/WT-07-054.1

[18] Bailey, W.A., Wilson, H.P. and Hines, T.E. (2002) Response of Potato (Solanum tuberosum) and Selected Weeds to Sulfentrazone. Weed Technology, 16, 651-658. https://doi.org/10.1614/0890-037X(2002)016[0651:ROPSTA]2.0.CO;2

[19] Brown, D. and Masiunus, J. (2002) Evaluation of Herbicides for Pumpkin (Curcurbita s). Weed Technology, 16, 282-292. https://doi.org/10.1614/0890-037X(2002)016[0282:EOHFPC]2.0.CO;2 
Submit or recommend next manuscript to SCIRP and we will provide best service for you:

Accepting pre-submission inquiries through Email, Facebook, LinkedIn, Twitter, etc. A wide selection of journals (inclusive of 9 subjects, more than 200 journals)

Providing 24-hour high-quality service

User-friendly online submission system

Fair and swift peer-review system

Efficient typesetting and proofreading procedure

Display of the result of downloads and visits, as well as the number of cited articles Maximum dissemination of your research work

Submit your manuscript at: http://papersubmission.scirp.org/

Or contact as@scirp.org 